\title{
LAZER, IMOBILIÁRIO E INFRAESTRUTURA URBANA DO LITORAL CEARENSE NO SÉCULO XXI
}

\author{
Alexandre Queiroz Pereira \\ Professor do Departamento de Geografia - UFC \\ aqpereira@ufc.br \\ lara Rafaela Gomes \\ Professora do Departamento de Geografia - UFC \\ iara.gomes@ufc.br
}

\begin{abstract}
RESUMO
No território brasileiro, as aglomerações urbanas localizadas próximas ao oceano integraram a sua porção mar, e, no século XX, essa dinâmica incrementa-se em função de práticas marítimas de lazer. Como resultado, percebe-se a expansão-fragmentação das formas e dos conteúdos da urbanização, como, por exemplo, a metropolização do espaço. Objetiva-se discutir as dimensões relacionadas à gestão municipal do espaço litorâneo cearense, especialmente dos municípios litorâneos em processo de metropolização. A hipótese é que a difusão das práticas marítimas gera, também, redefinições nas ações de planejamento e gestão públicas nos entes municipais. Para comprová-la, refere-se à capacidade de arrecadação de impostos, assim como o atendimento de demandas crescentes de infraestruturação dos espaços à beira-mar. Como estratégia investigativa, analisa-se o incremento tributário e a arrecadação a partir do parque imobiliário estabelecido em municípios litorâneos, sobretudo o Imposto sobre a Propriedade Predial e Territorial Urbana e o Imposto sobre a Transmissão de Bens Imóveis. Utilizou-se, ainda, a base de dados do Índice de Bem-estar Urbano. Conclui-se que as atividades turísticas e a vilegiatura demandam a tecnificação do território, especialmente através do processo de incorporação imobiliária. Entretanto, a arrecadação de impostos não significa apenas êxito, mas transformações territoriais acompanhadas de diversas precariedades básicas.
\end{abstract}

Palavras-chave: Lazer. Imobiliário. Infraestrutura. Ceará. Impostos.

\section{LEISURE, REAL ESTATE AND URBAN INFRASTRUCTURE OF CEARA'S COAST IN THE $21^{\mathrm{ST}}$ CENTURY}

\begin{abstract}
The large urban clusters located close to the ocean have integrated the sea portion of Brazilian territory and, in the twentieth century, these dynamics increased due to leisure activities performed on the seashore. As a result, the expansion-fragmentation of the forms as well as the contents of urbanization is noticeable, such as the metropolization of spaces. The aim of this paper is to discuss the dimensions of municipal management of the coastal area of Ceará, especially the seashore municipalities currently undergoing a process of metropolization. The hypothesis is that the spread of maritime practices also redefines the public planning and management actions of the municipal agencies. In order to demonstrate it, reference is made to the capacity of collecting taxes, as well as to the ability to meet the growing demands for infrastructures of the seaside spaces. It was analyzed the real estate taxes increase and collection in coastal municipalities, especially IPTU (Municipal Property Tax) and ITBI (Real Estate Transfer Tax). The IBEU (Urban Welfare Index) database was also used. It was concluded that the tourist activities and the holiday season require the technification of the territory, especially through the process of real estate incorporation. However, tax collection is not only a measure of success but also implies territorial transformations followed by several basic deficiencies.
\end{abstract}

Keywords: Leisure. Real Estate. Infrastructure. Ceara. Taxes. 


\section{INTRODUÇÃO}

O Brasil segue a tendência mundial e histórica do que se conhece como a "corrida para o mar" (BOUDOU, 2001). Há, contudo, necessidade de interpretar os contornos desse fato, pensando nas características e nos desdobramentos socioespaciais. No território nacional, as grandes aglomerações urbanas situadas próximas ao oceano incorporaram o seu lado mar, principalmente a partir do século XX, em função de práticas marítimas turísticas e de lazer (DANTAS, 2015). Como desdobramentos, observa-se a expansão-fragmentação das formas e dos conteúdos da urbanização, entre elas a metropolização do espaço (LENCIONI, 2013).

Nesse sentido, a compreensão dos desdobramentos da urbanização litorânea requer esforço contínuo, sobretudo na atualização de metodologia, fato que inclui a busca por variáveis/indícios que possam ser correlacionados. Assim, estudos de Hall e Müller (2004) e de Boyer (2008) contabilizaram e descreveram as segundas residências (casas e apartamentos) a partir de indicadores como localização, padrões urbanístico-arquitetônicos, perfil socioeconômico e cultural dos vacanciers (turistas e vilegiaturistas).

Com o mesmo intuito, Pereira $(2015 ; 2017)$ pensou acerca da relação entre práticas marítimas de lazer e a urbanização-metropolização, através da elaboração de metodologia experimental para a compreensão da costa nordestina do Brasil. Baseado em Dantas (2015), estabelece como ponto de partida três características fundantes dessa costa: i) em relação à morfologia, observou-se a fragmentação e a linearidade do tecido urbano; ii) no que tange à temporalidade, destacou-se a sazonalidade, com base em amplitudes de fluxos de vacanciers; iii) na dimensão social, pensou-se em fenômeno massificado, em virtude da difusão do gosto pelo mar e pelo marítimo em diversos estratos sociais.

Acredita-se que a difusão das práticas marítimas gera, também, redefinições nas ações de planejamento e gestão públicas nos entes municipais. De maneira mais específica, refere-se à capacidade de arrecadação de impostos, assim como ao atendimento de demandas crescentes de infraestruturação dos espaços à beira-mar como saneamento básico, vias de acesso, drenagem, melhoramentos urbanísticos dos espaços públicos, entre outras. A partir dessa hipótese, este artigo se propõe a discutir dimensões diretamente relacionadas à gestão municipal do espaço litorâneo cearense, sobretudo dos municípios litorâneos em processo de metropolização.

A metodologia operacional deste trabalho baseou-se em trabalhos de campo com a finalidade de reconhecer as tipologias de empreendimentos imobiliários e as condições de infraestrutura nas praias metropolitanas, utilizando-se de formulários de campo. Em seguida, reuniram-se informações a partir da base de dados do Tesouro Nacional e do Banco Central do Brasil (valores nominais atualizados com base na inflação do período) e do Observatório das Metrópoles (índice de bem-estar urbano). Além do mais, em gabinete, foram analisados planos diretores e demais legislações municipais, sobretudo a lei de uso e ocupação e o código tributário municipal. Esse conjunto de procedimentos e dados aparece decisivamente na leitura da transformação do espaço urbano litorâneo metropolitano ao longo da primeira década do século XXI.

É analisado, detalhadamente, o conjunto de causas e consequências derivadas da urbanização marcada pela fragmentação espacial e pela sazonalidade dos fluxos e demandas. Para isso, são compreendidos e apresentados dois conjuntos de indicadores em duas seções deste texto.

Primeiramente, analisa-se o que a priori denominam-se efeitos positivos da expansão do imobiliário no litoral. Consideraram-se o incremento tributário e a arrecadação a partir do parque imobiliário estabelecido em municípios litorâneos, sobretudo o Imposto sobre a Propriedade Predial e Territorial Urbana (IPTU) e o Imposto sobre a Transmissão de Bens Imóveis (ITBI). Tais informações foram sistematizadas com base no banco de dados disponibilizado pela Secretaria do Tesouro Nacional.

Num segundo momento, investigou-se o papel e as ações públicas para atender as demandas infraestruturais e as precariedades derivadas do consumo do espaço litorâneo. Empiricamente, selecionou-se a descrição das condições do entorno dos domicílios urbanos situados em distritos à beira-mar.

Os dados foram utilizados no caso cearense, com ênfase em municípios litorâneos metropolitanos, principais expressões da urbanização litorânea no Estado. Utilizou-se a base de dados sintetizada por Ribeiro e Ribeiro (2013), elaboradores do Índice de Bem-estar Urbano (IBEU), indicador que busca avaliar a proporção urbana do bem-estar desfrutado pela população brasileira a partir, resumidamente, do seu consumo mercantil, bem como dos serviços sociais prestados pelo Estado.

$\begin{array}{llllll}\text { Caminhos de Geografia } & \text { Uberlândia - MG } & \text { v. 19, n. } 67 & \text { Set/2018 } & \text { p. 109-125 Página } 110\end{array}$


A partir do IBEU, há possibilidade de investigar parâmetros de mobilidade urbana, condições ambientais urbanas, condições habitacionais urbanas, atendimento de serviços coletivos urbanos e infraestrutura urbana para os 15 grandes aglomerados que o Instituto Nacional de Ciência e Tecnologia (INCT), por meio do Observatório das Metrópoles, identificou em outros estudos como as metrópoles brasileiras, por realizarem funções de comando dos fluxos econômicos, em especial. Em nossa análise, a inserção desse índice colaborou para que pudéssemos examinar a situação da infraestrutura dos espaços litorâneos e sua relação com o incremento do lazer.

As reflexões neste texto nos permitem afirmar que as atividades turísticas e a vilegiatura demandam uma tecnificação do território, especialmente através do processo de incorporação imobiliária. A arrecadação de impostos (IPTU e ITBI), a princípio, apresenta-se como sinônimo de êxito dos investimentos públicos no propósito de obter incentivos privados. Entretanto, quando se verificam as condições de infraestrutura dos lugares à beira-mar onde se situam os desdobramentos imobiliários do lazer marítimo, percebem-se muitas transformações territoriais acompanhadas de precariedades básicas, como veremos a seguir.

\section{IMOBILIÁRIO DE USO SAZONAL E A ARRECADAÇÃO MUNICIPAL PRÓPRIA (ITBI E IPTU)}

A costa cearense tem aproximadamente $573 \mathrm{~km}$ de extensão e é subdividida em 20 territórios municipais. Nessas municipalidades residem quase 3 milhões e 600 mil habitantes, tendo havido, entre os períodos censitários apontados na Tabela 1, um aumento de mais de 500 mil moradores, aumento esse notado proporcionalmente em todas as municipalidades (IBGE, 2011). Os dados demonstram a relevância deste recorte espacial, sem, contudo, apontar para um quadro demográfico homogêneo. Observam-se quantitativos expressivos em Fortaleza, Caucaia e Itapipoca. Por outro lado, apresentam-se municípios com populações inferiores a 20 mil habitantes como Icapuí, Jijoca de Jericoacoara, Barroquinha e Fortim.

Tabela 1: População residente e densidade populacional em municípios litorâneos

\begin{tabular}{|c|c|c|c|c|}
\hline Município & 2000 & 2010 & $\begin{array}{c}\text { Diferença } \\
2010 / 2000\end{array}$ & $\begin{array}{c}\text { Densidade } \\
\text { populacional } \\
2010\left(\mathrm{hab} / \mathrm{km}^{2}\right)\end{array}$ \\
\hline Fortaleza* & 2.141 .402 & 2.452 .185 & 310.783 & $7.786,44$ \\
\hline Caucaia* & 250.479 & 325.441 & 74.962 & 264,91 \\
\hline Itapipoca & 94.369 & 116.065 & 21.696 & 71,90 \\
\hline Aquiraz* & 60.469 & 72.628 & 12.159 & 150,50 \\
\hline Aracati & 61.187 & 69.159 & 7.972 & 56,32 \\
\hline Cascavel $^{*}$ & 57.129 & 66.142 & 9.013 & 78,99 \\
\hline Camocim & 55.448 & 60.158 & 4.710 & 53,48 \\
\hline Acaraú & 48.968 & 57.551 & 8.583 & 68,31 \\
\hline Trairi $^{*}$ & 44.527 & 51.422 & 6.895 & 55,55 \\
\hline Beberibe & 42.343 & 49.311 & 6.968 & 30,37 \\
\hline São Gonçalo Do Amarante* & 35.608 & 43.890 & 8.282 & 52,60 \\
\hline Amontada & 32.333 & 39.232 & 6.899 & 33,27 \\
\hline Itarema & 30.347 & 37.471 & 7.124 & 52,00 \\
\hline Paracuru* & 27.541 & 31.636 & 4.095 & 105,35 \\
\hline Paraipaba* & 25.462 & 30.041 & 4.579 & 99,83 \\
\hline Cruz & 19.779 & 22.479 & 2.700 & 68,13 \\
\hline Icapuí & 16.052 & 18.392 & 2.340 & 43,43 \\
\hline Jijoca de Jericoacoara & 12.089 & 17.002 & 4.913 & 83,02 \\
\hline Fortim & 12.066 & 14.817 & 2.751 & 53,48 \\
\hline Barroquinha & 13.921 & 14.476 & 555 & 37,76 \\
\hline Total & 3.081 .519 & 3.589 .498 & 507.979 & - \\
\hline
\end{tabular}

* Municípios metropolitanos

Fonte: Sinopse do IBGE, 2001 e 2011. 
No que se refere à dispersão-aglomeração da urbanização no território, observa-se padrão espacial no qual a população e o tecido urbano concentram-se entre a costa e a linha imaginária paralela distante cerca de $10 \mathrm{~km}$. Forma-se o que denominamos de espaço de urbanização litorânea. $\mathrm{O}$ polígono formado concentra as sedes municipais (principais aglomerações urbanas) e as aglomerações em espaços à beira-mar, principalmente os balneários marítimos, à exceção de Fortaleza, como demonstra sua população total e a densidade demográfica $\left(7.786,44 \mathrm{hab} / \mathrm{km}^{2}\right)$. O lado mar das municipalidades tornou-se sítio no qual se compreende a reprodução do espaço urbano, visto que concentra a maior densidade populacional, do imobiliário, do sistema viário, dos serviços públicos e dos privados. Justifica-se, pois, o uso da expressão urbanização litorânea (PEREIRA, 2015).

As atividades de lazer, sobretudo o turismo e a estada temporária (vilegiatura marítima), são fatores contribuintes para a consolidação dessa configuração territorial. Dados da Secretaria de Turismo do Ceará (Setur) e do Instituto Brasileiro de Geografia e Estatística (IBGE) confirmam a direção dos fluxos de turistas e a construção de imobiliário destinado à estada temporária (domicílios particulares de uso ocasional/segundas residências), preferencialmente na zona costeira, nos trechos à beiramar. A análise detalhada desses dados pode ser consultada em Pereira (2014); Pereira, Araújo e Silveira (2016). Quanto menor o parque imobiliário permanente dos municípios mais evidente se torna o papel dos domicílios de uso ocasional e dos seus usuários na organização dos territórios litorâneos, conforme pode ser evidenciado em Gomes (2017), em estudo de outros casos.

A composição do imobiliário de uso estacional e seus impactos são o objetivo desta seção do artigo. Como demonstrado em Dantas et al. (2010), a existência desse subsetor do imobiliário tem relevância não somente pelo aumento no número de domicílios particulares no espaço construído municipal, mas também pela dinamização da formalização e legalização das negociações imobiliárias, influenciando diretamente na arrecadação própria dos municípios. Entre os anos de 2000 e 2010, todos os municípios litorâneos apresentaram crescimento no número de domicílios, quadro semelhante ao número de domicílios de uso sazonal (Tabela 2 e Gráfico 1). Essa hipótese é transformada, inclusive, em critério de eficiência administrativa pelas municipalidades quando do anúncio da construção de condomínios e complexos turísticos em seus respectivos territórios. Configura-se, portanto, em uma política de atração de investimentos privados que, em tese, garantirá novos postos de trabalho e maior dinâmica econômica para a municipalidade.

Gráfico 1: Número de domicílios de Uso Ocasional no litoral cearense (2000-2010)

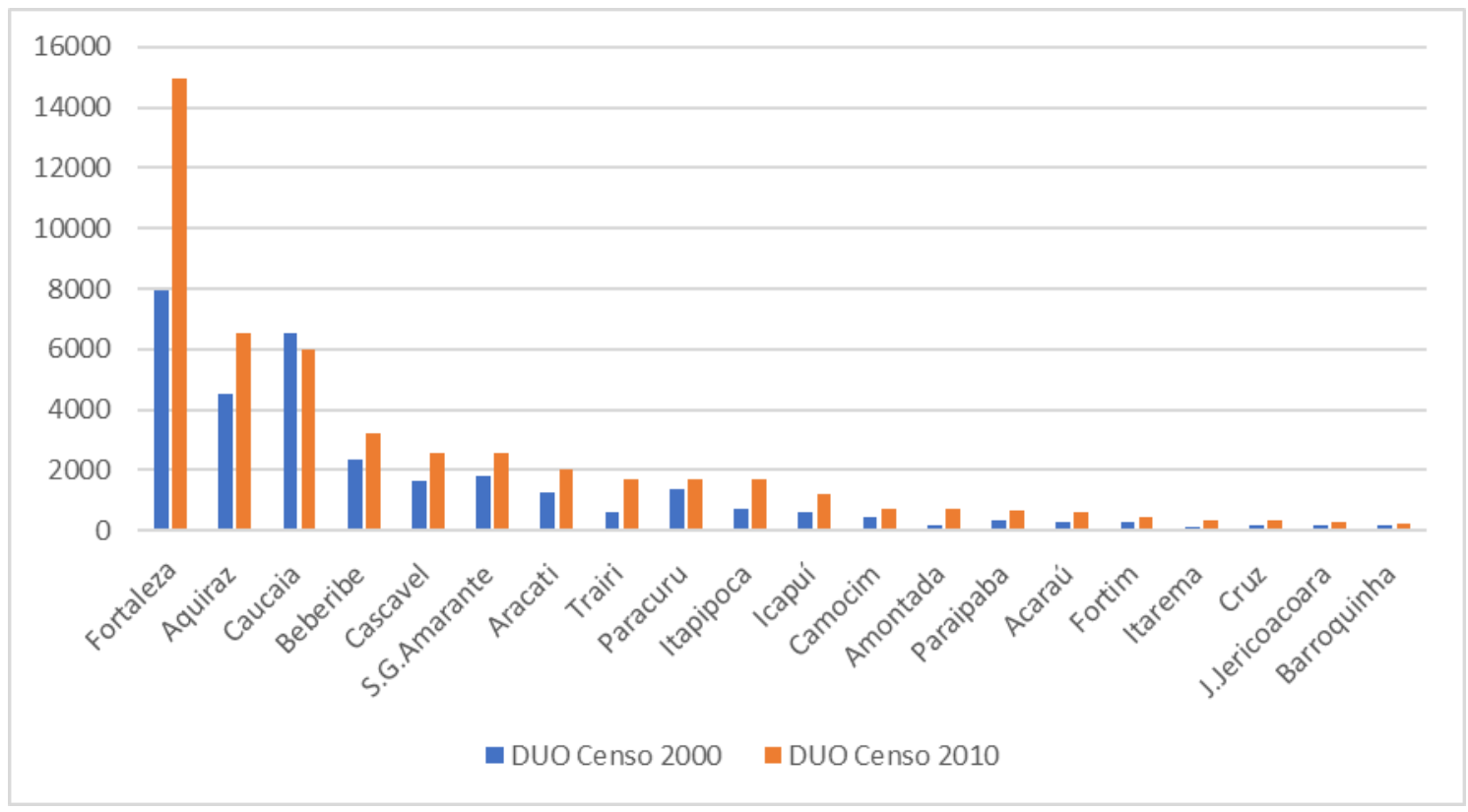

Fonte: Sinopse do Censo de 2000 e 2010. 
Tabela 2: Domicílios particulares permanentes em municípios litorâneos do

\begin{tabular}{|c|c|c|c|}
\hline \multicolumn{4}{|c|}{ Estado do Ceará } \\
\hline Município & 2000 & 2010 & Diferença 2010/2000 \\
\hline Fortaleza* & 525.991 & 709.952 & 183.961 \\
\hline Caucaia* & 59.347 & 89.183 & 29.836 \\
\hline Itapipoca & 20.531 & 29.918 & 9.387 \\
\hline Aracati & 14.224 & 19.763 & 5.539 \\
\hline Aquiraz* & 14.014 & 19.661 & 5.647 \\
\hline Cascavel $^{*}$ & 13.714 & 18.806 & 5.092 \\
\hline Camocim & 12.046 & 15.682 & 3.636 \\
\hline Acaraú & 10.343 & 14.628 & 4.285 \\
\hline Beberibe & 9.967 & 14.073 & 4.106 \\
\hline Trairi $^{*}$ & 9.496 & 13.337 & 3.841 \\
\hline São Gonçalo do Amarante* & 8.319 & 12.000 & 3.681 \\
\hline Amontada & 6.759 & 9.807 & 3.048 \\
\hline Itarema & 5.964 & 8.881 & 2.917 \\
\hline Paracuru* ${ }^{*}$ & 6.205 & 8.719 & 2.514 \\
\hline Paraipaba* & 5.677 & 8.178 & 2.501 \\
\hline Cruz & 4.375 & 6.167 & 1.792 \\
\hline Icapuí & 3.795 & 5.222 & 1.427 \\
\hline Jijoca de Jericoacoara & 2.677 & 4.714 & 2.037 \\
\hline Fortim & 2.813 & 4.137 & 1.324 \\
\hline Barroquinha & 2.983 & 3.707 & 724 \\
\hline
\end{tabular}

(*) Municípios inclusos na Região Metropolitana de Fortaleza.

Fonte: Sinopses do censo do IBGE, 2001 e 2011.

É possível verificar tal hipótese ao relacionar o número de domicílios particulares com o valor arrecado pelas municipalidades através de dois institutos tributários: IPTU e ITBI. No caso do Nordeste brasileiro, vários estudos têm buscado identificar o avanço do imobiliário-turístico nos últimos anos. Silva (2013a), por exemplo, mostra que, em um período de 10 anos (2000/2010), a região recebeu mais empreendimentos em seu litoral do que nos trinta anos anteriores (1970/2000). A maioria desses empreendimentos se instalou no litoral, na primeira linha de praia, com investimentos de capital estrangeiro, principalmente de origem espanhola.

Chamou-nos a atenção, também, considerando o investimento estrangeiro, a forte correlação dos processos aqui verificados com o caso de Alicante, na Espanha, em especial no que diz respeito ao mercado imobiliário, o lazer e a produção do espaço. Dominguez Martínez et al. (2016, p. 4) destacam que

[...] una de las consecuencias directas derivadas del proceso turístico residencial es, por tanto, el consumo desmesurado de suelo al que se ha aludido. Concretamente, la provincia de Alicante se ha visto tremendamente afectada. Durante las últimas décadas, este proceso de crecimiento ha estado acompañado por el incremento del número de extranjeros residentes en la provincia de Alicante y, particularmente, por el aumento de población de nacionalidad noreuropea. De forma especial, a partir del final de la década de los años 90 y a comienzos del siglo XXI, el crecimiento de población de ciertos municipios costeros se produce de paralelamente al incremento de superficie ocupada de los mismos.

Nesse sentido, consideramos relevantes os indicadores associados à arrecadação tributária e ao número de domicílios particulares para o entendimento da expansão desse processo, já defendido por Arrais (2013) quando analisou os casos da Região Metropolitana (RM) de Goiânia e de Fortaleza. Metodologicamente, entendeu-se que a avaliação estrita dos valores absolutos arrecadados menosprezaria a diferenciação entre escalas e magnitudes. Por exemplo, Fortaleza e Caucaia têm número de domicílios permanentes superior aos demais municípios litorâneos.

Dessa forma, pensou-se na formulação de uma razão simples e proporcional entre o número de domicílios permanentes e o valor em reais arrecadado em quatro marcos temporais $(2000,2003$, 2008 e 2011). Esses marcos justificam-se pela associação a fatos e processos relacionados a promoção, empecilhos e incentivos ao desenvolvimento das práticas de lazer: obras e ações dos 
Programas de Desenvolvimento do Turismo no Nordeste (PRODETURs) e demais políticas públicas, ampliação do número de investimentos privados e crise econômica internacional.

Metodologicamente, após atualização e correção inflacionária, os valores arrecadados até 2008 foram relacionados ao número de domicílios registrados no censo de 2000 , enquanto os valores de 2011, aos dados do censo de 2010. A análise da arrecadação do IPTU indica formalização do parque imobiliário construído em zonas urbanas delimitadas por lei municipal.

$\mathrm{Na}$ maioria dos municípios, as leis de zoneamento e uso e ocupação do solo e os planos diretores têm classificado os espaços à beira-mar, e/ou na zona costeira, como áreas para expansão urbana. Nessas áreas são permitidos tanto o parcelamento em lotes como o adensamento de construções balizadas por maiores índices de aproveitamento e reprodução do solo urbano.

Ao examinar a Tabela 3, percebe-se, de imediato, a discrepância entre os valores absolutos arrecadados por Fortaleza e os recolhidos pelos demais municípios litorâneos, fato diretamente explicável pela maior complexidade do espaço urbano da capital. Contudo, esses mesmos dados já indicam números ascendentes e valores significativos em Aquiraz, Caucaia e Beberibe.

Tabela 3: Arrecadação de IPTU em municípios litorâneos do Estado do Ceará em Reais nos anos 2000, 2003, 2008 e 2011

\begin{tabular}{lrrrr}
\hline \multicolumn{1}{c}{ Município } & \multicolumn{3}{c}{2000} & \multicolumn{2}{c}{2008} & \multicolumn{1}{c}{2011} \\
\hline Fortaleza & & & & \\
Aquiraz & $116.060 .797,75$ & $101.112 .993,05$ & $113.406 .707,69$ & $172.071 .713,87$ \\
Caucaia & $835.621,61$ & $1.855 .747,56$ & $3.960 .660,79$ & $4.507 .873,80$ \\
Beberibe & $2.621 .120,92$ & $2.636 .538,44$ & $3.693 .965,47$ & $3.489 .462,29$ \\
Aracati & $249.338,66$ & $326.743,27$ & $443.059,55$ & $1.178 .139,19$ \\
Cascavel & $187.827,95$ & $354.195,92$ & $288.234,25$ & $553.479,84$ \\
J. de Jericoacoara & $111.476,10$ & $79.281,51$ & $17.566,47$ & $279.992,10$ \\
Paracuru & $12.816,65$ & $81.646,17$ & $102.223,94$ & $206.696,23$ \\
Camocim & $1.082,01$ & $41.253,63$ & $176.667,01$ & $190.092,07$ \\
S. G. do Amarante & $43.549,65$ & $40.152,03$ & $381.981,67$ & $174.314,37$ \\
Paraipaba & 0 & $130.218,85$ & $8.129,78$ & $119.472,99$ \\
Acaraú & $9.095,66$ & $26.763,65$ & $26.723,07$ & $94.527,28$ \\
Itapipoca & 0 & $12.890,59$ & $44.129,82$ & $90.485,35$ \\
Amontada & 0 & $30.273,74$ & $45.007,74$ & $62.068,24$ \\
Fortim & $12.513,35$ & $33.136,79$ & $8.670,73$ & $50.968,58$ \\
Icapuí & $23.405,44$ & $12.276,36$ & $21.848,45$ & $41.768,69$ \\
Itarema & $22.970,20$ & $27.537,33$ & $3.943,94$ & $32.104,37$ \\
Cruz & 0 & $13.843,38$ & $16.141,07$ & $15.061,37$ \\
Barroquinha & $4.620,62$ & $24.928,02$ & $9.072,96$ & $14.018,82$ \\
Trairi & $6.136,47$ & 788,58 & $3.240,53$ & $2.091,37$ \\
\hline
\end{tabular}

Valores corrigidos a partir de índices inflacionários e de acordo com Calculadora do Cidadão do Banco Central do Brasil.

Fonte: TESOURO NACIONAL (2016).

A ordem dos municípios campeões em arrecadação de IPTU coincide com a classificação daqueles com maior número de domicílios de uso ocasional (Gráfico 1). Esse fato não nos surpreende na medida em que corrobora a hipótese anteriormente citada. Contudo, é interessante perceber a intensidade e o rebatimento, proporcional, para o conjunto de municípios com realidades distintas em termos de população, parque imobiliário permanente e presença específica de imobiliário disponível aos fluxos e necessidades dos vacanciers (turistas e vilegiaturistas).

$\begin{array}{llllll}\text { Caminhos de Geografia } & \text { Uberlândia - MG } & \text { v. 19, n. } 67 & \text { Set/2018 } & \text { p. 109-125 } & \text { Página } 114\end{array}$


A evolução temporal do índice IPTU demonstra crescimento nos valores dos municípios de Jijoca de Jericoacoara, Paracuru, Caucaia (litoral oeste), Aracati, Beberibe e Aquiraz (litoral leste), conforme Figura 1. A priori, é possível associar esses valores à difusão das atividades de lazer, já que esses municípios sediam as principais localidades turísticas e de vilegiatura do litoral. É exatamente na primeira década do século XXI que cresce o número de empreendimentos do tipo condomínios e resorts na zona de praia desses municípios. Na maioria das municipalidades, com valores corrigidos, percebem-se resultados ascendentes nos anos de 2003 e 2008.

Figura 1: Arrecadação do IPTU por domicílios permanentes no litoral do Ceará $(2000,2003,2008$ e 2011)

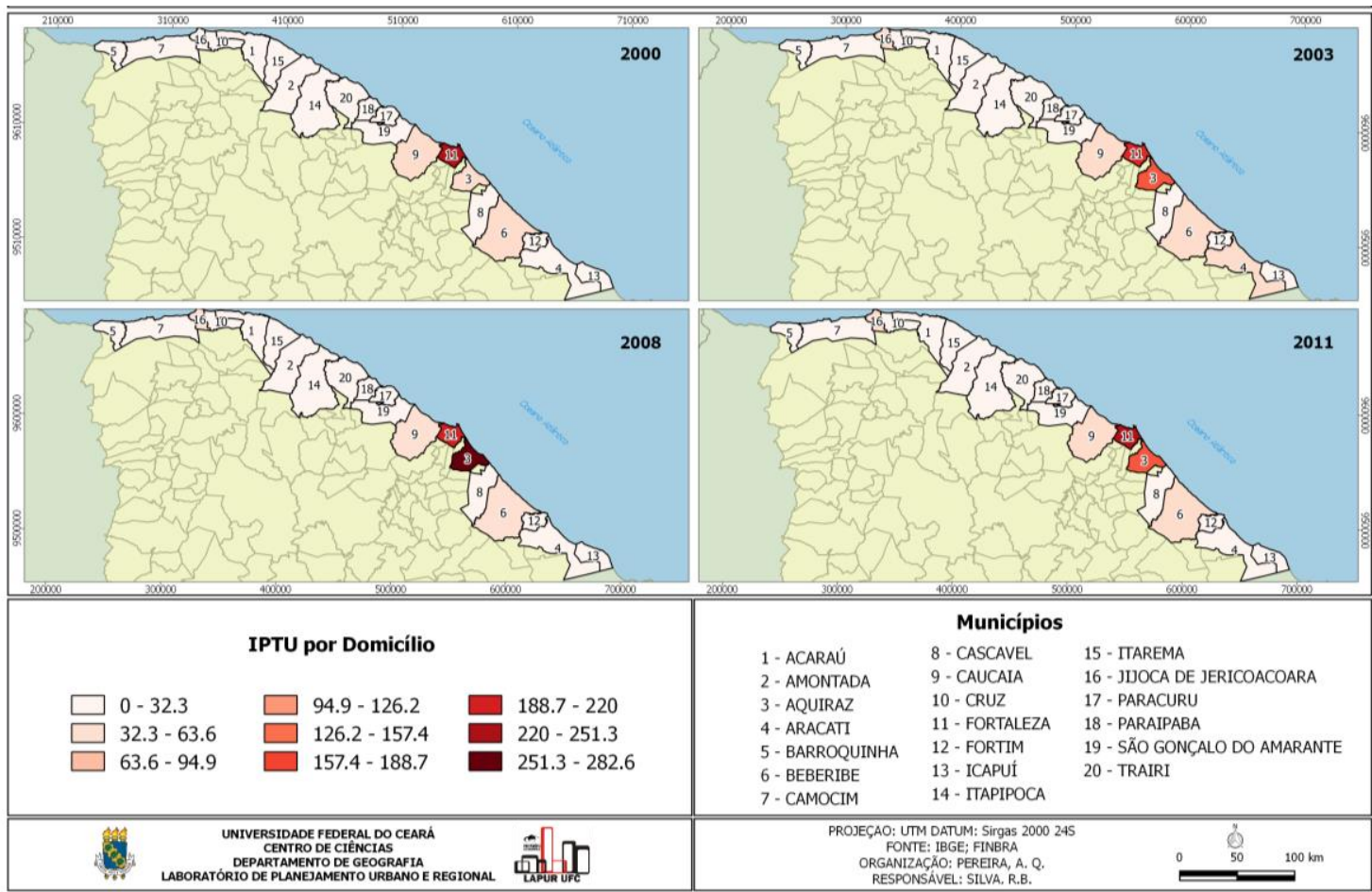

Nesse contexto, o município de Aquiraz também se destaca, pois arrecadou mais de 4,5 milhões de reais em 2011 com parque imobiliário de 19,7 mil domicílios particulares. Aquiraz apresenta-se como o segundo maior arrecadador, ultrapassando, inclusive, Caucaia, detentor de 89 mil domicílios permanentes. Para entender o caso de Aquiraz, é preciso considerar que nas praias de Porto das Dunas foram construídas dezenas de condomínios e resorts, como o complexo Beach Park, o Mandara e o Aquaville. No mesmo município, há ainda o maior complexo turístico do Estado, o Aquiraz Riviera. Essas condições e os dados de arrecadação sustentam a hipótese do crescimento arrecadatório, na aurora do século XXI, em virtude da urbanização do litoral para fins de lazer (Figura 2).

Figura 2: Empreendimento turístico e imobiliário no litoral metropolitano de Fortaleza

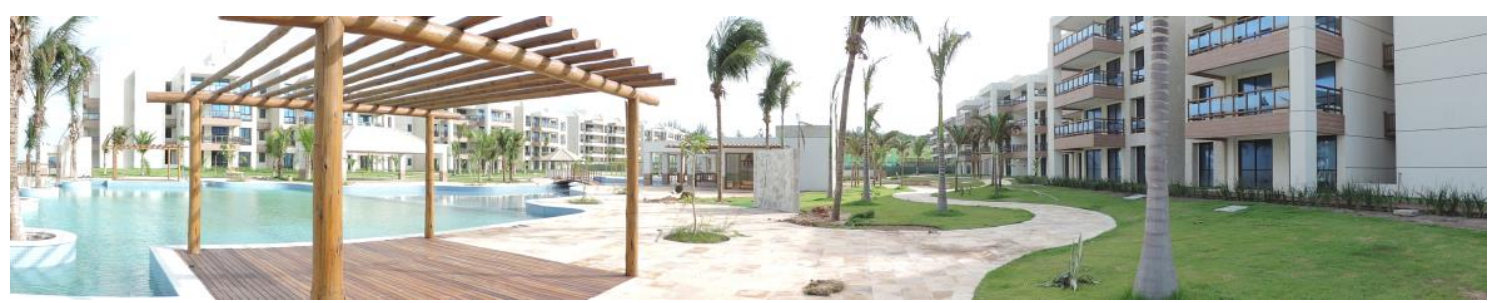

Vista interna de empreendimento residencial em construção na Praia de Cumbuco, em Caucaia-CE. Fonte: Arquivos dos autores, 2016. 
Em quantitativos inferiores, mas em condições semelhantes, observa-se o crescimento do número desses empreendimentos nas praias de Cumbuco (em Caucaia); de Morro Branco e Praia das Fontes (em Beberibe); nas praias de Flexeiras e Guajiru (em Trairi); na praia da Taíba (em São Gonçalo do Amarante); na vila de Jericoacoara e nas praias de Caponga e Águas Belas (em Cascavel).

Com o lazer à beira-mar, aumenta a diversidade de produtos imobiliários. Fala-se de residenciais multifamiliares, loteamentos para residências unifamiliares, resorts, condoresorts e dos já tradicionais hotéis e pousadas (SILVA, 2013b). Examinados os dois pares de anos - 2000/2003 e 2008/2011 -, percebe-se a consolidação do aumento proporcional de arrecadação de IPTU nos municípios que constituem as principais destinações de lazer litorâneo do Estado, inclusive o pequeno município sede da Vila de Jericoacoara, no litoral oeste do Ceará.

Também se comparou, a partir da mesma sistematização, os municípios que compõem a Região Metropolitana de Fortaleza (RMF), na Figura 3. Observa-se o comportamento dos municípios litorâneos e dos não litorâneos e conclui-se que os costeiros têm evolução diferenciada. Destarte, Aquiraz e Caucaia, respectiva e hierarquicamente, mesmo em estágios distintos, apresentam maiores índices se comparados a municípios como Maracanaú e Pacajus, cuja base econômica se assenta na industrialização.

Esses dois últimos municípios industriais exibem indicadores semelhantes ao longo do recorte temporal, com razões entre 17 e 19 (reais arrecadados por número de domicílios permanentes). No mesmo período, Aquiraz saltou da classe inicial para a relação entre 59 a 282 (reais arrecadados por número de domicílios permanentes). Outro município destacável é Eusébio. A municipalidade sedia uma série de projetos imobiliários do tipo condomínio fechado padrão "Alphaville", um deles próximo à localidade de Porto das Dunas, na divisa com Aquiraz. Caracteriza-se como espacialidade marcada pela expansão das atividades de moradia e lazer de classes abastadas.

Figura 3: Índice de arrecadação do IPTU por domicílios no litoral da RMF $(2000,2003,2008$ e 2011)

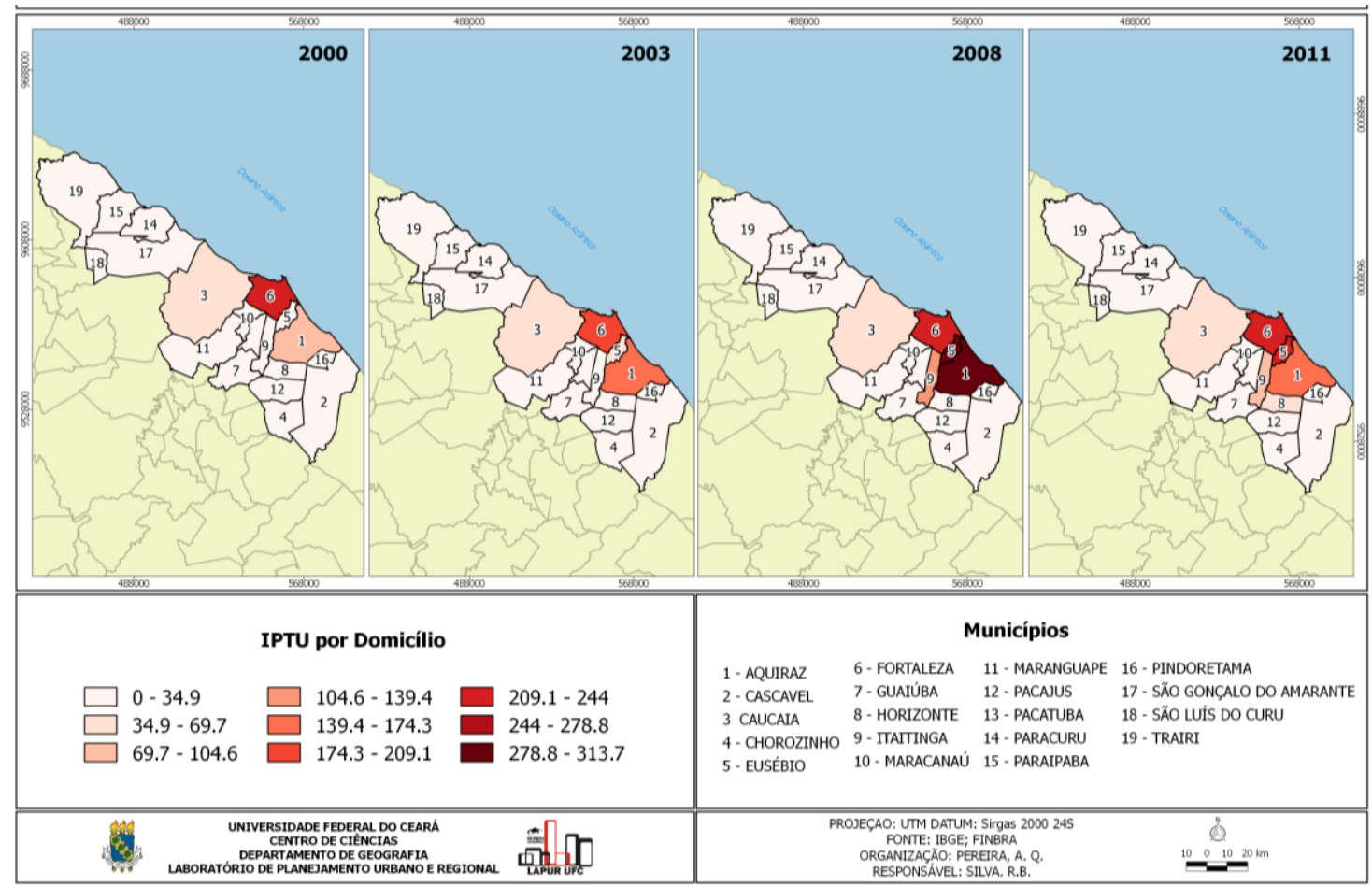

Outro indicador para a análise é o índice de arrecadação ITBI, que revela o fluxo de negociações imobiliárias do tipo compra e venda em dado território municipal. O imposto abarca transações envolvendo tanto lotes como áreas construídas, imóveis usados ou projetos recém-inaugurados.

$\begin{array}{llllll}\text { Caminhos de Geografia } & \text { Uberlândia - MG } & \text { v. 19, n. } 67 & \text { Set/2018 } & \text { p. 109-125 } & \text { Página } 116\end{array}$


Nesse sentido, vale contextualizar alterações dos tipos imobiliários predominantes comercializados entre o pré e pós anos 2000. A configuração territorial litorânea, inclusive, é também resultado dos novos padrões de imobiliário que atendem as demandas urbanas e por lazer marítimo, crescentes em metrópoles litorâneas (PEREIRA et al., 2016). Antes do século XXI, preponderavam, nos municípios litorâneos, a construção e a venda de loteamentos, inclusive nas zonas de praia (mais precisamente na planície litorânea). Atualmente, são comuns vendas de residências em projetos multifamiliares (condomínios).

Essa alteração tem impacto direto nos recursos arrecadados, pois tais imóveis têm maior valor venal, o que aumenta, proporcionalmente, os valores absolutos repassados às finanças municipais (Tabela 4). Outra justificativa para esse impacto encontra-se no campo técnico-administrativo. Após a formulação e a aprovação de legislação regulatória (em destaque o Plano Diretor), as municipalidades aperfeiçoaram os sistemas de fiscalização e arrecadação de impostos.

Tabela 4: Arrecadação de ITBI em municípios litorâneos do Estado do Ceará em Reais nos anos 2000, 2003, 2008 e 2011.

\begin{tabular}{|c|c|c|c|c|}
\hline Município & 2000 & 2003 & 2008 & 2011 \\
\hline Fortaleza & $35.851 .290,29$ & $27.421 .982,90$ & $54.003 .318,95$ & $88.285 .646,87$ \\
\hline Aquiraz & $680.888,36$ & $1.126 .743,31$ & $5.218 .885,31$ & $3.920 .137,28$ \\
\hline Caucaia & $836.950,35$ & $684.608,82$ & $1.570 .405,89$ & $2.653 .070,22$ \\
\hline S. G. do Amarante & $33.778,21$ & $102.228,47$ & $442.570,55$ & $477.499,84$ \\
\hline Aracati & $77.033,14$ & $78.170,46$ & $247.722,47$ & $437.366,27$ \\
\hline Beberibe & $217.612,70$ & $264.356,41$ & $438.824,94$ & $393.320,05$ \\
\hline Cascavel & $126.478,35$ & $133.134,56$ & $240.306,76$ & $305.315,73$ \\
\hline Trairi & $69.360,43$ & $97.165,11$ & $498.992,48$ & $272.943,89$ \\
\hline Paracuru & $39.214,93$ & $4.484,51$ & $1.016 .553,70$ & $231.797,85$ \\
\hline J. de Jericoacoara & $6.848,27$ & $182.144,09$ & $85.543,35$ & $182.437,54$ \\
\hline Camocim & $36.442,19$ & $25.197,55$ & $75.582,49$ & $181.689,10$ \\
\hline Paraipaba & $27.552,33$ & $27.606,03$ & $79.427,69$ & $127.657,23$ \\
\hline Acaraú & $24.656,60$ & $10.542,83$ & $34.937,57$ & $126.440,82$ \\
\hline Itapipoca & 0 & $35.877,40$ & $61.417,18$ & $109.893,90$ \\
\hline Itarema & $10.297,32$ & $6.246,61$ & $14.501,10$ & $68.734,17$ \\
\hline Fortim & $42.441,50$ & $1.604,04$ & $57.641,04$ & $55.537,55$ \\
\hline Amontada & $6.265,95$ & $9.885,89$ & $7.620,11$ & $18.190,76$ \\
\hline Icapuí & 466,84 & $1.918,46$ & $31.299,79$ & $16.739,85$ \\
\hline Cruz & $11.637,07$ & $36.819,53$ & $10.106,28$ & $7.655,05$ \\
\hline Barroquinha & 0 & $1.617,20$ & $1.492,97$ & $1.000,00$ \\
\hline
\end{tabular}

Valores corrigidos a partir de índices inflacionários e de acordo com Calculadora do Cidadão do Banco Central do Brasil.

Fonte: TESOURO NACIONAL (2016).

Semelhantemente ao que ocorrera com o índice IPTU, o referente ao ITBI demonstra intensificação do impacto do arrecadado em municípios com funções de lazer fortalecidas por investimentos públicos e privados. Em termos absolutos, o salto quantitativo, a partir dos anos 2010, é inegável, sobretudo em Aquiraz, São Gonçalo do Amarante, Caucaia e Beberibe (Figura 3). Aquiraz, novamente, é caso de destaque, pois contabilizou em 2011 valor bem superior ao arrecadado em 2000 , alcançando, em valores corrigidos, aproximadamente 5 milhões de reais em 2008 e $R \$ 4$ milhões em 2011 (Tabela 4). 
Ao evidenciar o caso dos municípios litorâneos e a arrecadação do ITBI, percebe-se mudança relevante com início na segunda metade dos anos 2000. Os municípios litorâneos metropolitanos, mais Beberibe e Aracati, proporcionalmente, elevaram a arrecadação própria por meio desse tributo. Existiram variações anuais, o que se explica pelo maior ou menor número de empreendimentos lançados e a velocidade de venda, todavia há constatação do aumento da relação entre o número de domicílios e o montante total recolhido pelas municipalidades. Na razão matemática estabelecida pelo índice de arrecadação, é destacável o ano de 2008 como marco na comercialização de imóveis, mormente em Aquiraz, Paracuru, Beberibe, São Gonçalo do Amarante e Trairi (Figura 4).

Figura 4: Índice de arrecadação do ITBI por domicílios no litoral do Ceará (2000, 2003, 2008 e 2011)

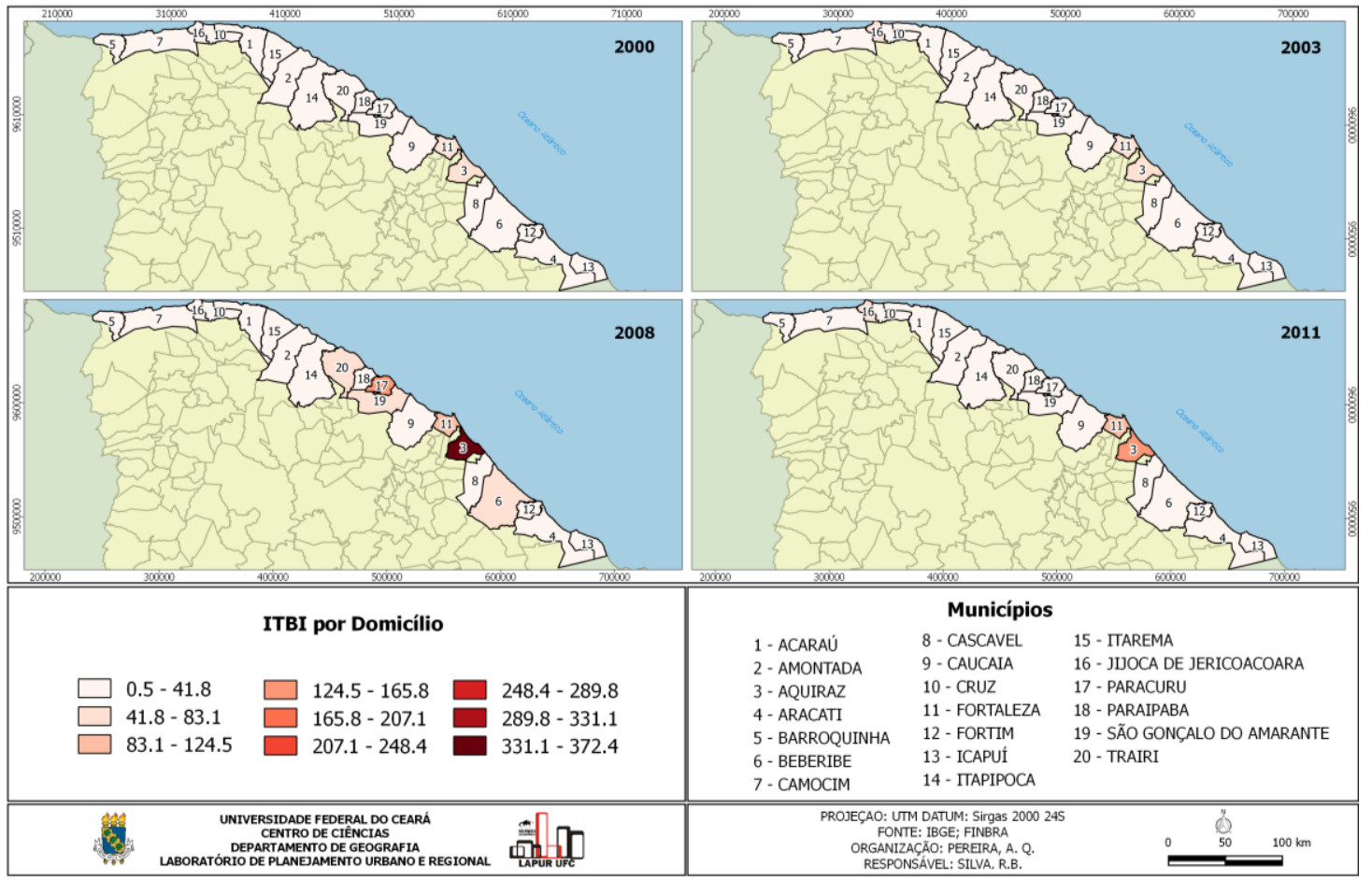

As vendas de projetos imobiliários na planície costeira estão diretamente relacionadas aos empreendimentos destinados ao lazer, tanto de cearenses, muitos moradores de Fortaleza, como de residentes de outras regiões do país. Em pesquisa recente, Cunha (2017) destaca a contínua produção de empreendimentos turísticos imobiliários nos espaços litorâneos da RMF. Essa produção de imóveis novos é um dos fatores propulsores de arrecadação de ITBI para esses municípios. A produção do espaço urbano em função dos empreendimentos turístico-imobiliários representa valorização do solo e maior valor venal dos imóveis comercializados. Essa dimensão tem impacto direto nos montantes arrecadados nos municípios destacados.

Há, até aqui, clareza de que os municípios litorâneos apresentaram elevação do montante de impostos arrecadados. Nos espaços litorâneos, o padrão de reprodução do tecido urbano e as imposições legais (tributárias, urbanísticas e ambientais) impõem dinâmica semelhante à que ocorre em cidades como Fortaleza. Todavia, é de conhecimento que a inadimplência no pagamento dos impostos é fator preocupante para as administrações municipais (com destaque para o IPTU).

A consulta ao banco de dados de contas públicas, acessado via Tesouro Nacional, permite inferir que os orçamentos dos municípios litorâneos apresentam dependência das transferências de outros entes federativos. Em média, a arrecadação própria significa 30\% do orçamento e há casos, não tão raros, em que o percentual é menor que $10 \%$. Já o IPTU e o ITBI, considerados em conjunto, representam entre $10 \%$ e $40 \%$ da arrecadação própria municipal. Dada essa circunstância, é possível conjecturar a possibilidade de crescimento arrecadatório em municípios litorâneos com dinâmica turísticoimobiliária, fato já perceptível em cidades como Aquiraz e Caucaia.

$\begin{array}{llllll}\text { Caminhos de Geografia } & \text { Uberlândia - MG } & \text { v. 19, n. } 67 & \text { Set/2018 } & \text { p. 109-125 Página } 118\end{array}$


Nesses termos, cabe o questionamento sobre a suficiência dos montantes recolhidos pelo fisco municipal para atender as demandas de infraestrutura e serviços urbanos básicos. Sabe-se que os empreendimentos de lazer consomem considerável área dos municípios e fomentam fluxos sazonais de visitantes.

Há maior pressão para qualificar os espaços públicos e as vias de acesso a esses conjuntos imobiliários para o lazer. Somados os valores do IPTU e ITBI recolhidos por Aquiraz no ano de 2011, obteve-se o total de $\mathrm{R} \$ 8,42$ milhões. Mas será que essa arrecadação própria gera autonomia para a municipalidade organizar seus espaços, sobretudo, os turísticos? É preciso considerar os problemas enfrentados pelas municipalidades e construir uma "cultura do pagamento" de impostos vinculados à propriedade do imóvel nas demais áreas ou zonas dos territórios municipais (sede ou distritos), mesmo sendo consideradas pelos planos diretores como de expansão urbana. Para tanto, são necessárias atualizações nos códigos tributários (redução de isenções tributárias) e eficiência técnica na fiscalização e na emissão de alvarás. As proporções demonstram a fragilidade orçamentária das municipalidades litorâneas, fato deveras limitador da capacidade de promover projetos de reestruturação urbana.

\section{A REVERSÃO DOS IMPOSTOS E AS INFRAESTRUTURAS URBANAS NO ESPAÇO LITORÂNEO}

$\mathrm{Na}$ secção anterior, defendeu-se a hipótese de que o atual imobiliário para o lazer instalado no espaço litorâneo cearense, especificamente na sua porção mais à beira-mar, tem importante influência na arrecadação de dividendos para o erário municipal. Tal evidência é importante na dimensão da análise para a compreensão do que chamamos de formas-conteúdo da urbanização litorânea.

A reprodução do urbano no espaço litorâneo é cercada por tentativas de regulação do uso do solo, de onde deriva o aprimoramento do sistema de arrecadação de impostos próprios das "zonas urbanas". No que tange à forma, nota-se a expansão do espaço construído, do imobiliário, incluindo-se na configuração territorial característica desse recorte. Todavia, frente ao avanço desse front urbano tão importante para os territórios municipais, pergunta-se: quais as condições do entorno desses imóveis? Quais as condições básicas de infraestrutura em zonas de praias urbanizadas? Para tal interpretação, pensou-se na utilização do IBEU, elaborado por Ribeiro e Ribeiro (2013).

Ribeiro e Ribeiro (2013, p. 9) destacam o seguinte:

O IBEU contém cinco dimensões: mobilidade urbana; condições ambientais urbanas; condições habitacionais urbanas; atendimento de serviços coletivos urbanos; infraestrutura urbana. E cada uma dessas dimensões é constituída por um conjunto de indicadores, construídos a partir do censo demográfico do Instituto Brasileiro de Geografia e Estatística (IBGE) de 2010.

Os autores destacam ainda que

"[...] a concepção de bem-estar urbano presente neste trabalho que estamos propondo decorre da compreensão daquilo que a cidade deve propiciar às pessoas em termos de condições materiais de vida, a serem providas e utilizadas de forma coletiva. Neste aspecto, estamos nos afastando de uma concepção de bem-estar decorrente do consumo individual e mercantil, seja no sentido da busca de maximização de utilidades, centrada na realização do autointeresse, seja no sentido do ótimo de Pareto. Apesar de o bem-estar ser experimentado individualmente, procuramos considerar nessa concepção o bem-estar que se constitui e se realiza no plano coletivo, daí o sentido do urbano na determinação do bem-estar" (RIBEIRO e RIBEIRO, 2013, p. 9).

O índice varia de zero (condições precárias) a um (quadro satisfatório) e pode ser lido espacialmente, tanto na escala global (comparação entre metrópoles) como na local (análise de áreas de ponderação na escala intrametropolitana). Essa última é a utilizada neste trabalho, conforme Tabela 5.

Em termos metodológicos, quatro das cinco dimensões analisadas consideram as vias de acesso e os espaços públicos no entorno dos domicílios. A exceção consta no item condições habitacionais urbanas, que se utiliza de indicadores cuja realidade depende da renda dos proprietários (Quadro 1). O índice demonstra ser útil na averiguação de condições infraestruturais dos espaços litorâneos alcançados pelo tecido urbano que se reproduz em função de lazer. 
Quadro 1: Indicadores das dimensões que integram o IBEU

\begin{tabular}{|c|c|c|c|c|}
\hline $\begin{array}{c}\text { Mobilidade } \\
\text { urbana }\end{array}$ & $\begin{array}{c}\text { Condições } \\
\text { ambientais } \\
\text { urbanas }\end{array}$ & $\begin{array}{c}\text { Condições } \\
\text { habitacionais } \\
\text { urbanas }\end{array}$ & $\begin{array}{l}\text { Serviços } \\
\text { coletivos } \\
\text { urbanos }\end{array}$ & $\begin{array}{c}\text { Infraestrutura } \\
\text { urbana }\end{array}$ \\
\hline $\begin{array}{l}\text { Tempo de } \\
\text { deslocamento } \\
\text { casa-trabalho }\end{array}$ & $\begin{array}{l}\text { - Arborização no } \\
\text { entorno do } \\
\text { domicílio } \\
\text { - Esgoto a céu } \\
\text { aberto no } \\
\text { entorno do } \\
\text { domicílio } \\
\text { - Lixo } \\
\text { acumulado nos } \\
\text { logradouros }\end{array}$ & $\begin{array}{l}\text { - Aglomerado } \\
\text { subnormal } \\
\text { - Densidade } \\
\text { domiciliar } \\
\text { - Densidade de } \\
\text { banheiro } \\
\text { - Parede } \\
\text { - Espécie do } \\
\text { domicílio }\end{array}$ & $\begin{array}{l}\text { - Atendimento } \\
\text { de Água } \\
\text { - Atendimento } \\
\text { de Esgoto } \\
\text { - Coleta de Lixo } \\
\text { - Atendimento } \\
\text { de Energia }\end{array}$ & $\begin{array}{l}\text { - Iluminação } \\
\text { pública } \\
\text { - Pavimentação } \\
\text { - Calçada } \\
\text { - Meio-fio } \\
\text { - Bueiro ou boca } \\
\text { de lobo } \\
\text { - Rampa para } \\
\text { cadeirante } \\
\text { - Logradouro }\end{array}$ \\
\hline
\end{tabular}

Fonte: Ribeiro e Ribeiro (2013).

$\mathrm{Na}$ escala metropolitana, analisaram-se quatro municípios litorâneos e seus dez setores à beira-mar: Três em Aquiraz, três em Cascavel, dois em Caucaia e dois em São Gonçalo do Amarante. O IBEU, no nível de detalhe aqui destacado, não considerou a atual formação da RMF, composta hoje por Fortaleza e mais sete municípios litorâneos. Acredita-se, contudo, que o exame dos quatro casos, espaço de expansão metropolitana, é representativo para as questões e análises propostas, fato justificável pela maior concentração de empreendimentos de lazer construídos nesses espaços.

Ao examinar a Tabela 5, evidenciam-se os piores índices parciais nos serviços coletivos urbanos e infraestrutura. Tal condição foi diagnosticada em texto anterior de Pereira (2010) e, agora, referendada pelos dados oficiais. Os bairros e as demais formas de ocupação nesses trechos do território metropolitano não estão atendidos pela rede de abastecimento de água e tampouco pela rede de coleta de esgoto.

Os empreendimentos turístico-imobiliários (resorts, complexos imobiliários, entre outros) perfuraram poços profundos para captação de água subterrânea. Em relação ao esgoto, as estações de tratamento de efluentes são estruturas exigidas pelos órgãos de regularização ambiental. Já os imóveis unifamiliares utilizam-se das fossas negras, reconhecidamente inadequadas para ambientes naturais com solos arenosos e permeáveis.

Nesse sentido, vale lembrar o processo de ocupação dos espaços litorâneos cearenses. Até os anos 1960, predominavam vilarejos de pescadores, com baixa densidade demográfica e imobiliária. Com a metropolização das atividades de lazer, elevou-se o número de moradores e, sobretudo, o número de visitantes (vilegiaturistas ou turistas). As condições pré-turistificação eram suficientes para atender as demandas dos pescadores e demais moradores. Contudo, com a expansão do tecido urbano (pós anos 1970), baseada, quase unicamente, na construção de imóveis (segundas residências), os improvisos infraestruturais avolumaram-se, gerando rugosidades precárias, refletidas em muitas das condições ineficientes encontradas no presente.

As principais transformações infraestruturais em nosso objeto de estudo aconteceram entre o final dos anos 1990 e 2014, em virtude do desenrolar do PRODETUR/NE (em suas diversas fases) e dos empréstimos contraídos pelo Estado em instituições financeiras internacionais. As intervenções que demandaram maior volume de recursos foram a construção ou duplicação de rodovias que dão acesso aos balneários, como a CE-040 (rodovia sol nascente) e a CE-085 (rodovia sol poente) (CASTRO, 2016). Todavia, obras que mudariam o panorama apontado pelo IBEU restringiram-se a um número pequeno de localidades, concentrando-se nos municípios de Caucaia (Cumbuco) e São Gonçalo do Amarante (Taíba). 
Tanto os condomínios como os complexos turísticos imobiliários produzem internamente condições urbanísticas tecnicamente aceitáveis e mundialmente disseminadas. São ajardinados e têm espaços coletivos, praças e calçadas. Subterraneamente, há um sistema de drenagem e escoamento de águas pluviais. Mas tudo isso é cercado por muros. No conjunto das ocupações no litoral, percebemse vias públicas sem pavimentação e sem calçadas, principalmente em áreas de expansão urbana, heranças dos anos 1970 e 1980, período de multiplicação de loteamentos litorâneos, parcialmente ocupados, e não dotados das infraestruturas necessárias e exigidas por lei. São nesses loteamentos onde a maioria dos empreendimentos e as segundas residências foram e são construídas.

O avanço de serviços e infraestruturas urbanas se fez mais incidente na eletrificação e na coleta de resíduos sólidos. Todavia são serviços disseminados especialmente para essa coleta, pois a elevação da população em períodos de estada dos vacanciers produz quantidade de resíduos superior à capacidade de recolhimento. É comum nas faixas de praia, em trechos com adensamento de usuários, o acúmulo e a dispersão de resíduos derivados diretamente das práticas de lazer. Proprietários de empreendimentos privados, como as barracas de praia, realizam pontual e parcialmente esse recolhimento no seu entorno imediato.

Ainda na Tabela 5, também, podemos perceber que as condições habitacionais são ruins e médias, isto é, nenhum município foi classificado com boas condições. Do ponto de vista das condições ambientais urbanas, os dados mostraram-se controversos ao que encontramos primariamente, em decorrência de a escala espacial de agrupamento dos dados incluir setores mais continentais e, também, próximos às sedes municipais.

Contudo, quando aproximamos a escala no intraurbano das localidades litorâneas (mais especificamente dos trechos à beirar-mar), as fotografias a seguir nos ajudam na análise detalhada e complementar aos quantitativos do índice (Figura 5). Tal relação necessita de maior aprofundamento, sendo de nosso interesse uma pesquisa no cruzamento do item infraestrutura com o de condições ambientais urbanas.

Tabela 5: Índice de Bem-estar Urbano por setor litorâneo metropolitano e por dimensão

\begin{tabular}{llccccc}
\hline Setor & Município & $\begin{array}{c}\text { Mobilidade } \\
\text { Urbana }\end{array}$ & $\begin{array}{c}\text { Condições } \\
\text { Ambientais } \\
\text { urbanas }\end{array}$ & $\begin{array}{c}\text { Dimensões } \\
\text { Condições } \\
\text { habitacionais }\end{array}$ & $\begin{array}{c}\text { Serviços } \\
\text { coletivos } \\
\text { urbanos }\end{array}$ & Infraestrutura \\
\hline Área 001 & Aquiraz & 0,949 & 0,941 & 0,666 & 0,353 & 0,314 \\
Área 002 & Aquiraz & 0,940 & 0,923 & 0,692 & 0,342 & 0,372 \\
Área 003 & Aquiraz & 0,938 & 0,841 & 0,768 & 0,487 & 0,391 \\
Área 001 & Cascavel & 0,877 & 0,940 & 0,718 & 0,338 & 0,477 \\
Área 002 & Cascavel & 0,931 & 0,843 & 0,776 & 0,471 & 0,562 \\
Área 003 & Cascavel & 0,948 & 0,836 & 0,767 & 0,469 & 0,418 \\
Tabuba & Caucaia & 0,871 & 0,757 & 0,727 & 0,447 & 0,440 \\
Icaraí & Caucaia & 0,878 & 0,732 & 0,746 & 0,396 & 0,302 \\
Área 001 & S. G. de & 0,941 & 0,919 & 0,746 & 0,665 & 0,550 \\
& Amarante & 0,940 & & & & \\
Área 002 & S. G. de & 0,944 & 0,773 & 0,711 & 0,489 & 0,387 \\
& Amarante & & & & & \\
\hline
\end{tabular}

Fonte: IBEU, 2013.

Fato destacável e, aparentemente, contraditório diz respeito às condições dos serviços coletivos urbanos em Aquiraz. O munícipio, como demonstrado no primeiro ato, em termos proporcionais, tem maior arrecadação dos tributos IPTU/ITBI; contudo, seus índices estão entre os níveis mais baixos. O maior número de imóveis e, também, o maior número de vilegiaturistas geram demanda superior somada às carências históricas não resolvidas pela municipalidade. Sem investimentos públicos de outras esferas (estadual e federal), a municipalidade não apresenta capacidade financeira para arcar com projetos urbanísticos e infraestruturais. Situação semelhante se detecta em outros municípios metropolitanos. Estabelece-se um modelo de urbanização baseado na adequação-qualidade dos espaços internos aos empreendimentos turístico-imobiliários, sem, entretanto, ter a mesma 
modelização para espaços e acessos públicos do entorno. Ainda que em solo à beira-mar tão valorizado, ocorre uma urbanização precária.

Os acessos à faixa de praia são exemplo do que foi mencionado acima. Na maioria das capitais litorâneas são produzidos espaços públicos como calçadões, vias paisagísticas litorâneas, ciclovias e/ou vias de acesso direto à praia, diferentemente do que foi constatado nas áreas localizadas nos municípios em análise. Grosso modo, o acesso nessas áreas estudadas é feito através de ruas estreitas (mais próximas de vielas/beco) e/ou por espaço privado de empreendimentos como as barracas de praia, muito comuns no litoral cearense. Esse quadro não é restrito ao caso cearense. Podem-se observar condições semelhantes em municípios do litoral potiguar, como os estudos de Silva (2009) apontaram.

Há problemas registrados em relação à erosão costeira, sobretudo nas praias de Caponga, em Cascavel, e de Icaraí, em Caucaia. Esse fenômeno tem reduzido a faixa de praia e exigido a implementação de sistemas de engenharia para a contenção do processo. Via de regra, essas obras carecem de recursos financeiros superiores à capacidade de endividamento próprio desses municípios.

Figura 5: Exemplo de precariedades na infraestrutura das praias na RMF
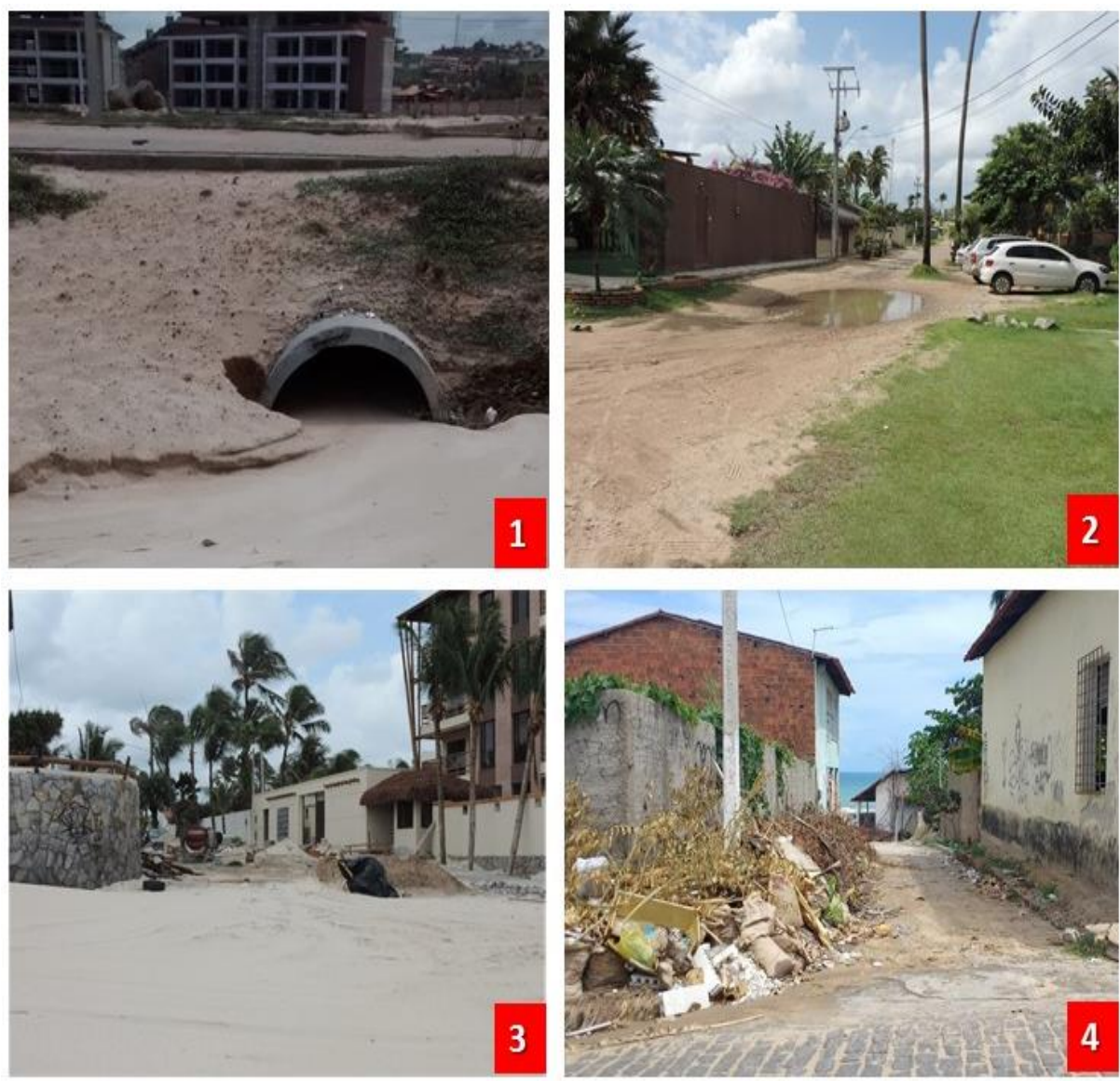

1. Deficiência na rede de drenagem à beira-mar em Porto das Dunas, em Aquiraz; 2. Ausência de pavimentação, calçadas e drenagem em Cumbuco, Caucaia; 3. Dificuldades de acesso à praia em Cumbuco; 4. Acúmulo de resíduos sólidos em vielas na Taíba, em São Gonçalo do Amarante.

Fonte: Trabalho de Campo do Grupo de Estudos sobre Urbanização Litorânea, 2016.

Há verdadeira subversão do que, comumente, associamos à vida comunitária nesses municípios. Ficam claras a difícil governabilidade por parte da gestão municipal e a falta de um projeto político que suplante os objetivos diretos da chamada "sociedade do lazer". Por isso, consideramos relevante conhecer os consumidores desse litoral, isto é, aqueles que impulsionam a expansão do tecido 
urbano no espaço litorâneo desses municípios e que nos ajudam não somente a ler e captar os fenômenos em análise, mas, ainda, compreender a quem se destinam os investimentos em todo um conjunto de objetos e ações custeado, em grande parte, pelo recolhimento de tributação sobre a propriedade imobiliária ou sobre a negociação dos bens imóveis.

As pendências infraestruturais descritas para o caso dos espaços à beira-mar avolumam-se no tempo e no espaço. Há confirmação de que os recursos públicos são restritos frente às demandas. Todavia, as municipalidades, em sua função de controle do uso e ocupação do espaço, não analisam o impacto de um modelo de urbanização baseada na dispersão linear de empreendimentos de médio e grande porte na planície litorânea. Essa dispersão encarece a instalação de infraestruturas e o fornecimento de serviços públicos eficientes, sobretudo no período de maior concentração de visitantes.

De maneira geral, as piores condições de bem-estar urbano encontram-se nas metrópoles das regiões Norte e Nordeste do país. Isso se aplica, portanto, a municípios pertencentes a essas metrópoles. No entanto, do mesmo modo que há diferenças entre as metrópoles naquilo que podemos considerar como principais problemas urbanos, elas relativizam a questão urbana do presente, a depender tanto da região metropolitana, a que nos referimos, como dos municípios.

O estudo comparativo dos municípios, de fato, reforça, ainda mais, as diferenças entre as regiões metropolitanas do país, mas aponta especialmente para as diversidades internas existentes em cada uma. Isso demonstra que, quando estamos falando das condições urbanas, sejam das metrópoles brasileiras, sejam de seus municípios, é fundamental que tais municipalidades não sejam consideradas como um todo homogêneo.

\section{CONSIDERAÇÕES FINAIS}

O experimento de argumentação desenvolvido neste artigo trouxe importantes apontamentos. O primeiro deles é de caráter metodológico, na medida em que a utilização de índices e fontes qualitativas demonstrou eficácia na análise e na proposição de hipóteses. Refere-se mais precisamente à influência de lazeres no processo de urbanização de trechos do litoral brasileiro.

Inicialmente, pode-se afirmar que as atividades turísticas e a vilegiatura (estada temporária) demandam uma tecnificação do território, especialmente através do processo de incorporação imobiliária, processo esse diverso tanto pelos formatos como pelos agentes sociais envolvidos. Como um dos subprodutos constatados está o incremento fiscal nas municipalidades. A arrecadação de impostos (IPTU e ITBI), em primeira análise, apresenta-se enquanto sinônimo de eficácia e positividade dos investimentos públicos no intuito de atrair incentivos privados. Os recursos oriundos dessas fontes são de fato expressivos, ainda mais se comparados às limitações de arrecadação e orçamento dos municípios brasileiros. O exemplo mais destacável é o caso de Aquiraz, cuja arrecadação de IPTU e ITBI corresponde em média a 40\% do total de receita própria.

Quando, no entanto, verificam-se as condições de infraestrutura dos lugares à beira-mar onde se situam os desdobramentos imobiliários do lazer marítimo, percebem-se muitas transformações territoriais acompanhadas de condições básicas precárias. Fala-se aqui da fragilidade ou mesmo inexistência de calçadas, pavimentação nas ruas, drenagem, cuidado com espaços públicos e oferecimento de serviços coletivos básicos. Os dados do IBEU, nesse caso, são demonstrativos. Verifica-se que, apesar dos incrementos arrecadatórios, as municipalidades não conseguem atender as demandas que crescem no tempo e no espaço.

O fato é que, nos dias atuais, percebe-se o incremento das desigualdades urbanas nas principais metrópoles do país bem como em outros espaços não metropolitanos. Para pensar sobre essa questão, o IBEU propiciou a análise intraurbana de um conjunto de municípios do país (RIBEIRO; RIBEIRO, 2013) e estudá-lo, em nosso caso, permitiu-nos afirmar que, com o aumento do fluxo de visitação e estada (população flutuante), essas carências, que materializam as desigualdades, tornam-se mais evidentes. Para corrigir os problemas infraestruturais, as municipalidades recorrem, nem sempre com êxito, ao tesouro estadual ou mesmo a investimentos públicos federais.

Tecnicamente, os municípios apresentam deficiências na formação de equipe de servidores responsáveis pelo acompanhamento e pela atualização do plano diretor. Grosso modo, há necessidade de financiamento estadual para a contratação de empresas de consultoria, a fim de elaborar diagnósticos e proposições. Além disso, são pertinentes medidas de controle do uso do território, sobretudo as que avaliem a potencialidade de arrecadação própria, as concessões, as

\begin{tabular}{llllll}
\hline Caminhos de Geografia & Uberlândia - MG & v. 19, n. 67 & Set/2018 & p. 109-125 & Página 123
\end{tabular}


isenções fiscais e as novas demandas criadas: coleta de lixo, uso de recursos hídricos, acesso e criação de espaços públicos e preservação ambiental e paisagística.

Além dos impostos cobrados dos empreendimentos de grande porte (resorts, parques temáticos, complexos turísticos, condomínios com dezenas de unidades unifamiliares), as municipalidades deveriam elaborar normas e leis, apoiadas no Estatuto da Cidade, com o objetivo de solicitar dos grupos empresariais responsáveis, antes da instalação dos projetos, contrapartidas infraestruturais na localidade onde esses empreendimentos vão se instalar. Pensar unicamente na qualidade urbanística e arquitetônica do empreendimento em si, tende a degradar a qualidade urbanística e social da totalidade do espaço litorâneo reproduzido. Em termos de gestão e planejamento, a médio e longo prazo, os problemas se tornarão insolúveis e podem ser custosos aos cofres públicos.

\section{AGRADECIMENTOS}

Este texto teve origem nas reflexões desenvolvidas ao longo de nossa participação no núcleo Fortaleza do Observatório das Metrópoles (sediado no Laboratório de Planejamento Urbano e Regional - Lapur/UFC) e em projeto de pesquisa financiado pelo CNPq através do Edital Universal de 2014.

\section{REFERÊNCIAS}

ARRAIS, T. A. Morar na metrópole, viver na praia ou no campo: a segunda residência e o mercado imobiliário. 1. ed. Goiânia: Editora da UFG, 2013.

BOUDOU, J-L. Em favor da talassografia. Geografia, Vitória, № 2, jun. 2001, p. 71-80.

BOYER, Marc. Les villégiatures du XVle au XXle siècle: Un panorama du tourisme sédentaire. Éditions EMS, 2008.

CASTRO, T. da S. O sol nasce para todos? Planejamento, turistificação e urbanização litorânea na Costa do Sol Poente do Ceará. 2016. 295 f. Dissertação (Mestrado) - Curso de Geografia, Universidade Federal do Ceará, Fortaleza, 2016. Disponível em:

<http://www.repositorio.ufc.br/handle/riufc/20080>. Acesso em: 20 fev. 2017.

CUNHA, G. B. Urbanização litorânea e Planejamento na metrópole: a produção do espaço urbano de Fortaleza. 2017. Dissertação (Mestrado em Geografia) - Universidade Federal do Ceará, 2017.

DANTAS, E. W. C.; FERREIRA, A. L. (Org.); LIVRAMENTO, M. C. (Org.). Turismo e imobiliário nas metrópoles. 1. ed. Rio de Janeiro: Letra Capital, 2010, v. 1, 224p.

DANTAS, E. W. C. Incorporação do lado mar à geografia das metrópoles nordestinas. Boletim Goiano de Geografia (Online), v. 35, p. 380-396, 2015.

DOMÍNGUEZ MARTÍNEZ, Laura. CIRIQUIÁN, P.M.; CIRUGEDA, A.N. Turismo residencial de extranjeros en la Costa Blanca: su manifestación territorial y estudio de casos representativos. Scripta Nova. Revista Electrónica de Geografía y Ciencias Sociales. [En línea]. Barcelona: Universidad de Barcelona, 1 de noviembre de 2016, vol. XX, no 547. Disponível em: $<$ http://revistes.ub.edu/index.php/ScriptaNova/article/view/547>.

GOMES, I. R. Vilegiatura marítima como vetor da urbanização brasileira. Mercator (Fortaleza. Online), v. 16, p. 1/719-16, 2017.

HALL, C. M; MÜLLER, K. (edit.). Tourism, mobility and second homes: between Elite Landscape and Common Ground. Chanel View Publications: Cleveton/Bufalo/Toronto, 2004. https://doi.org/10.21832/9781873150825

IBGE. Instituto Brasileiro de Geografia e Estatística (Org.). Sinopse do Censo Demográfico 2000. Rio de Janeiro: Brasil, 2001.

IBGE. Instituto Brasileiro de Geografia e Estatística (Org.). Sinopse do Censo Demográfico 2010. Rio de Janeiro: Brasil, 2011. 
LENCIONI, Sandra. Metropolização do espaço: processos e dinâmicas. In: FERREIRA, A.; RUA, J; MARAFON, G. J.; SILVA A. C. P. (Org.). Metropolização do espaço. Gestão territorial e relações urbano-rurais. Rio de Janeiro: Consequência, 2013, v. 1, p. 17-34.

PEREIRA, A. Q. Urbanization-metropolization and holiday resorts on the northeast coast of Brazil. Mercator (Fortaleza. Online), v. 14, p. 107-121, 2015.

PEREIRA, A. Q.; ARAÚJO, E. F.; SILVEIRA, B. Planejamento urbano-turístico em Fortaleza: perspectivas pós-Copa 2014. Revista Novos Cadernos NAEA, v. 19, p. 275-292, 2016. https://doi.org/10.5801/ncn.v19i1.2207

PEREIRA, A. Q.; DANTAS, E. W. C.; GOMES, I. R.. Lazer na praia: segunda residência e imobiliário turístico no Nordeste. 1. ed. Fortaleza: Imprensa Universitária - UFC, 2016, 107p .

PEREIRA, A. Q.. A urbanização vai à praia: vilegiatura marítima e metrópole no Nordeste do Brasil. 1. ed. Fortaleza: Edições UFC, 2014.

PEREIRA, A. Q.. A vilegiatura marítima na metrópole: morfologias e tipologias espaciais. In: PEREIRA, A. Q; ARAÚJO, E.; SOARES JUNIOR, T.; SILVA, M. N.; SILVEIRA, B. (Org.).

Maritimidade na Metrópole: estudos sobre Fortaleza-CE. 1ed. Porto Alegre: Editora Liro, 2013, v. 1 , p. 9-47.

PEREIRA, A. Q.. Planejamento e metropolização do lazer marítimo em Fortaleza-Ceará, Nordeste do Brasil. EURE (Santiago. En línea), v. 43, p. 1-22, 2017.

PEREIRA, A. Q.. Praia do presídio: santuário da vilegiatura. Ateliê Geográfico (UFG), v. 3, p. $92-$ 110, 2010. https://doi.org/10.5216/ag.v3i3.8593

RIBEIRO, L. C. Q.; RIBEIRO, M. G. (Org.). Índice de bem-estar urbano. 1. ed. Rio de Janeiro: Letra Capital, 2013.

SILVA, K. de O. Condomínios fechados, residências secundárias e o uso do espaço público pelo capital imobiliário. Revista Acadêmica Observatório de Inovação do Turismo, v. IV, p. 1-15, 2009.

SILVA, M. N de F. O imobiliário-turístico no Nordeste brasileiro: o turismo residencial e a macrourbanização turística a partir expansão e expressão dos resorts residenciais no litoral. Dissertação (Mestrado). PPGGeografia, UFC, Fortaleza, 2013a. Disponível em: <http://www.repositorio.ufc.br/bitstream/riufc/8977/1/2013_dis_mnfsilva.pdf>.

SILVA, M. N de F. Os resorts residenciais na região metropolitana de Fortaleza (Ceará, Brasil). Turismo e sociedade, v. 6, p. 42-57, $2013 \mathrm{~b}$.

TESOURO NACIONAL (Brasil). Dados contábeis dos municípios, 2016. Disponível em: <http://www.tesouro.fazenda.gov.br/contas-anuais>. Acesso em: 09 jun 2018.

Recebido em: 06/09/2017

Aceito para publicação em: 04/07/2018 